\title{
THE IMPACT OF PEER MENTORING ON MARKETING CONTENT MASTERY
}

\author{
Lynn E. Metcalf, Stern Neill, Lisa R. Simon, Sharon Dobson, and Brennan Davis
}

\begin{abstract}
This article describes and assesses a course design that uses peer mentors to facilitate a collaborative, hands-on learning experience in an introductory marketing course. Results demonstrate that peer mentoring increased content mastery and had a positive effect on students' perceptions of the learning experience. Peer marketing mentors, along with the faculty team, achieved success in providing a demanding and engaging learning environment that meets the needs of learners and equips them with content knowledge required of career-ready professionals. A step-by-step guide is provided to enable others to develop a similar experience for students in their institutions.
\end{abstract}

The marketing faculty is responsible to key stakeholders-accreditors, employers, and students-for designing effective marketing curricula. In its revised standard, the Association to Advance Collegiate Schools of Business (2016) mandates that curricula deliver the knowledge and skills employers expect, engage students in learning, engender productive student-to-student and faculty-to-student interaction, and ensure that students achieve learning outcomes. Employers expect graduates of business schools to have foundational knowledge of marketing, as well as analytical skills that support evidence-based marketing decision-making (Finch, Nadeau, \& O'Reilly, 2012; Harrigan \& Hulbert, 2011; Schlee \& Harich, 2010). Students expect to graduate with knowledge and skills that prepare them for careers (Hershatter \& Epstein, 2010; Smith, 2012). These expectations present both challenges and opportunities for marketing educators to create the conditions that enhance student learning and development and prepare graduates for careers in

Lynn E. Metcalf (Ph.D., University of Oregon), Professor of Marketing, Orfalea College of Business, Cal Poly, San Luis Obispo, CA, lmetcalf@calpoly.edu

Stern Neill (Ph.D., Louisiana State University), Professor of Marketing, Orfalea College of Business, Cal Poly, San Luis Obispo, CA, sneill@calpoly.edu

Lisa R. Simon (MBA, University of Southern California), Marketing Lecturer, Orfalea College of Business, Cal Poly, San Luis Obispo, CA, 1simon@calpoly.edu

Sharon Dobson (MBA, University of Mississippi), Marketing Lecturer, Orfalea College of Business, Cal Poly, San Luis Obispo, CA, sdobson@calpoly.edu

Brennan Davis (Ph.D., University of California, Irvine), Associate Professor of Marketing, Orfalea College of Business, Cal Poly, San Luis Obispo, CA, bdavis39@calpoly. edu marketing. As with most marketing programs in a business school, the primary opportunity to establish foundational knowledge of marketing is the Principles of Marketing course.

In any given year at our university, which is part of a 23-campus statewide system, up to eight faculty members serve approximately 800 students in 15 sections distributed across three 10-week quarters (rather than semesters). With a strong learn-by-doing tradition at the university and college levels and a college vision statement that focused on experiential business education, interaction with industry professionals, experiential exercises, and project-based learning had been a core part of the Principles of Marketing experience in most sections of the course. In recent years, resource constraints had put pressure on class sizes. In large lecture sections, faculty members were spread too thinly to coach learn-by-doing projects effectively. In a 65-person section, with 13 teams, the faculty member could spend $8 \mathrm{~min}$ per team, at most-or $1.5 \mathrm{~min}$ of contact time per team member. With insufficient resources to keep class sizes small, pedagogy and materials began to vary widely by faculty member. Some continued to incorporate a multiphase, team-based project that demanded discovery and application. Others opted for cases that demanded critical thinking and application, while others reverted to the lecturetest method. The result was that the student experience, student engagement with the core marketing course and the marketing major, as well as mastery of key marketing concepts and processes began to decline, as measured by students' performance on key assurance of learning metrics.

As a faculty committed to experiential business education and to continuous improvement, we sought 
ways to leverage the resources available to us, so that we could universally return to collaborative, writingintensive assignments and projects in the Principles of Marketing course, achieve consistency, and deliver on the promise of content mastery and engagement. What we had going for us included the following:

1. A pool of highly qualified students in the business program. The new freshman profile for 2015 showed an average GPA of 3.99, ACT score of 30, and SAT score of 1330.

2. Experience using peer mentors in the college's advising center.

3. A group of faculty-nominated marketing students, who had distinguished themselves in marketing courses and who were among the top marketing students in the major.

Interested full-time faculty, who had 15-30 years of experience teaching Principles of Marketing, met to develop a course redesign, where $50 \%$ of class time was dedicated formally to breakout sessions to allow for interactive, experiential exercises and collaborative, project-based learning. These pedagogies have been proven to have a significant, positive effect on student learning (Kuh, 2008). To further the effect, an additional innovation was incorporated-a team of high-achieving marketing students as peer mentors to work directly with student teams during the breakout sessions. The use of peer mentors had the potential to support learning for both students and mentors (Rieske \& Benjamin, 2015).

As the efficacy of the pedagogical approaches used has already been demonstrated, the first goal for this study was to examine the effect of peer mentoring on content mastery, which is the acquisition of marketing knowledge, as well as the ability to explain, to interpret, to analyze and to apply that knowledge. The second goal was to evaluate the efficacy of the peer-mentoring program. The following four research questions were explored.

1. How does the use of peer mentors affect course participants' mastery of foundational knowledge of marketing?

2. How does the use of peer mentors affect student perceptions of the learning experience?

3. How does peer mentor's leadership development affect student learning?
4. How does the development of specific mentor leadership practices affect student learning?

Research on the use of peer mentors in a learning environment is limited (Rieske \& Benjamin, 2015). A recent review of the research on undergraduate peer mentoring programs points to the need for methodologically rigorous research that guides the development and continuous improvement of peer mentoring programs (Gershenfeld, 2014). This study addresses that need.

First, the literature on peer mentoring is reviewed, and hypotheses are presented. Next, the course and the mentoring program designs are described. A section on research methods, research results, and a discussion of the results follows. Last, suggestions for implementation at other institutions are offered and implications for future research and limitations are discussed.

\section{PEER MENTORING}

Mentoring refers to a situation in which a more experienced member of an organization provides information, support, and guidance to a less-experienced member of an organization (Campbell \& Campbell, 1997). Peer-to-peer mentoring has been identified as a high-impact educational practice (Kuh, 2008) and the value of consulting with knowledgeable peers in experiential learning has been demonstrated (cf. Parker, Hall, \& Kram, 2008; Schon, 1983; Sherman \& Burns, 2015). For mentors, peer mentoring strengthens the ability to become a leader within one's profession (Kram, 1988), facilitates personal learning (Lankau \& Scandura, 2002), and generates higher grades in subsequent courses (Amaral \& Vala, 2009). For the students working with peer mentors, mentoring adds educational and social value (Rieske \& Benjamin, 2015), resulting in stronger academic performance (Stevenson, Fox, Connelly, Duff, \& Dunlop, 2010), higher grades (Goff, 2011), and a higher overall perception of learning benefits (Smith, 2008) to the college student experience.

Peer mentoring provides productive student-to-student guidance that engages students in learning. Taylor (2007) noted the efficacy of peer-learning partnerships in learning was due in part to nonhierarchical status. Others have noted that students are experts at being students; therefore, they are uniquely positioned 
to lead novice students toward becoming expert students (Longfellow, May, Burke, \& Marks-Maran, 2008). Raska (2013) found that peer feedback was perceived as more supportive and positive. Similarly, work by Gosser, Kampmeier, and Varma-Nelson (2010) revealed that students perceived peer mentors to be approachable, which reduced anxiety. In addition, they found that students perceived the feedback and guidance from peers during peer-led learn-by-doing workshops as egalitarian and supportive.

A good peer mentor has been demonstrated to be knowledgeable and experienced, a connecting link, a leader, a role model, a guide to learning-someone with whom to share views and advice about the major, as well as trusted, approachable, and encouraging (Batty, Rudduck, \& Wilson, 1999; Burnett \& Pettijohn, 1999; Colvin \& Ashman, 2010; Gosser et al., 2010; Gray \& Smith, 2000; Jacobi, 1991; Rieske \& Benjamin, 2015; Rowley, 1999). Rieske and Benjamin (2015) noted the importance of training to support the development of these capabilities.

\section{HYPOTHESES}

This study's contribution relates to the use of peer mentors to facilitate collaborative, experiential, project-based learning, with the goal of improving content mastery and student perceptions of the learning experience. First, the study explores how the use of peer mentors affected course participants' mastery of foundational marketing knowledge. As noted previously, the literature shows that peer mentors do affect student learning. Mentors encourage and motivate students to become more engaged in learning, growth, and achievement (Jacobi, 1991), while cooperation among peers, social interaction between peers, and the provision of expert scaffolding by peers enables students to achieve greater learning (Falchikov \& Blythman, 2001).

Hypothesis 1: Students working with peer mentors will demonstrate greater content mastery than will students not working with peer mentors.

The second research question relates to how the use of peer mentors might affect student perceptions of the learning experience. Peer mentoring has been found to bring about effective changes in attitude to the classroom and the subject, as well as gains in student motivation, confidence, and enjoyment during class (Topping, 2005). Arendale and Hane (2014) found that students participating in a peer-assisted learning program experienced higher levels of academic engagement. Jacobi (1991) cited indirect support for the link between academic mentoring and satisfaction. In addition, satisfaction has been found to lead to more positive word-of-mouth behavior (Kleine, 2002).

Hypothesis 2: Students working with peer mentors will have more positive perceptions of the learning experience than will students not working with peer mentors.

The third research question addresses how peer mentors' overall leadership development affects student learning. Leadership development involves promoting practices that enable others to engage effectively and to make a meaningful difference (Posner, 2004). Particularly relevant to this study, leadership development involves building the capacity for student teams to learn their way out of problems. Jacobi (1991) notes the need for empirical studies that assess the effect of mentoring on students' personal development. In this study, peer mentors' perceptions of their own leadership development, how these perceptions evolve over the mentorship time period, and the effect on student learning are examined. Experience as a peer leader provides mentors with a more thorough knowledge of the discipline and to have a positive effect on the acquisition of professional behaviors and subsequent success (Amaral \& Vala, 2009; Anderson, Tenenbaum, Ramadorai, \& Yourick, 2015; Tenenbaum, Anderson, Jett, \& Yourick, 2014). Endress (2000) reports that training enhanced students' beliefs in their abilities to engage in leadership behaviors. Others (cf. Aderibigbe, Antiado, \& Sta Anna, 2015) find that, through the process of peer-to-peer mentoring, peer mentors develop their leadership skills, which increases their capacity to create conditions that are conducive to learning.

Hypothesis 3: The leadership development of peer mentors will positively affect content mastery by students.

Posner (2004) identifies the behaviors that students report when at "their personal best as leaders" and categorizes them into five leadership practices: 
1. Model the Way: Set an example for others on the basis of established standards.

2. Inspire a Shared Vision: Engage others in a common purpose.

3. Challenge the Process: Seek improvements by experimenting and taking risks.

4. Enable Others to Act: Involve others through collaboration and empowerment.

5. Encourage the Heart: Recognize the contributions of others.

These characteristics of student leaders are consistent with the conditions conducive to learning, which include a learner-centered approach that encourages self-directed learning; facilitators who are empathetic, caring, authentic and able to promote critical reflection; and ample opportunities for assessment and feedback (Brown \& Posner, 2001). We propose hypotheses related to each leadership practice.

Hypothesis 4a: Mentor development of Model the Way will positively affect content mastery by students.

Hypothesis 4b: Mentor development of Inspire a Shared Vision will positively affect content mastery by students.

Hypothesis 4c: Mentor development of Challenge the Process will positively affect content mastery by students.

Hypothesis 4d: Mentor development of Enable Others to Act will positively affect content mastery by students.

Hypothesis 4e: Mentor development of Encourage the Heart will positively affect content mastery by students.

The course and peer mentoring program designs are described below, followed by a presentation of the research methods and findings. An empirical test of the four hypotheses was conducted on the basis of two quarters of student data. Two quarters of student data provided an opportunity to assess the effect of program adjustments. The article concludes with a discussion of the findings along with challenges, limitations, and future research implications.

\section{PEER MENTOR PROGRAM AND COURSE DESIGN}

Effective incorporation of peer mentors was a key element of the course design. High-achieving marketing students were recruited to work directly with student teams during learn-by-doing sessions. Faculty- and self-nominated students submitted an application and résumé to the faculty coach, who was also a course instructor. Selection criteria included performance in marketing courses, engagement in marketing-related co-curricular activities, and marketing-related internships. The faculty coach interviewed and selected peer mentors to maintain an eight-person peer mentor cohort. To ensure program continuity, the cohort comprised both juniors and seniors. Peer mentors were paid $\$ 12$ per hour for about $10 \mathrm{hr}$ of work each week for 11 weeks and were funded by the college.

The undergraduate, junior-level Principles of Marketing course was redesigned with the goal of improving content mastery and student engagement. Students in all course sections worked in teams to accomplish a marketing project, which required them to develop a new product, conduct a strengths, weaknesses, opportunities, and threats (SWOT) analysis, and create a market launch strategy. All components of the marketing project required students to make evidence-based decisions that leveraged primary and secondary data. In addition to a final written marketing plan, students presented an executive summary of their projects in a pitch-style event. Students selfselected teams (four to six students per team), wrote a team contract, and evaluated their own and their teammates' performance.

All sections of the course were scheduled for ten weeks and met twice a week for two hours each day. One control section (without mentors) and four treatment sections (with mentors) were scheduled both quarters. The control section comprised 40 students in Quarter 1 and 64 students in Quarter 2. Treatment sections averaged 63 students per section and were taught by full-time faculty members, with 15-30 years of experience teaching Principles of Marketing. The instructor for Quarter 2's control class also taught a Quarter 2 treatment class.

Prior to the first class meeting of each week (Day 1), students completed quizzes on textbook chapters. On Day 1 of each week, faculty introduced key marketing frameworks and engaged students in short, 
collaborative activities and discussion. The Day 1 class meetings provided scaffolding for the Day 2 collaborative, learn-by-doing workshops. During the Day 2 workshops, students worked on components of their marketing projects, which were designed to reinforce the concepts learned on Day 1. Table 1 shows how Day 1 content mapped to the Day 2 learn-by-doing workshops. Students in the control condition met to work on their marketing projects without the help of peer mentors; whereas, students in the treatment condition met on Day 2 to work on their marketing projects with the help of peer mentors. In the control condition (without mentors), the instructor divided his /her coaching time among the teams in the course section. In the treatment condition (classes with mentors), each peer mentor worked with two to three teams. Peer mentors helped in two classes and mentored five to six teams during the quarter.
Each week, the peer mentors and faculty coach met to discuss leadership skills, coaching techniques, marketing knowledge, workshop strategy, and problemsolving tools. Two guest speakers, one a specialist in leadership and the other in teaching and learning, provided additional training and guidance. During the quarter, peer mentors completed exercises to address weaker leadership areas, such as developing trust and managing large collaborative projects.

One shortcoming noted with respect to the use of peer mentors is the tendency for peers to engage in 'knowledge-telling rather than knowledge-building' (Roscoe \& Chi, 2007). To address this potential shortcoming, peer mentors were trained to support knowledge and skill development and to facilitate learn-bydoing activities. They were trained to follow a 'scaffolding' approach, using examples, hints, questions and demonstrations to promote collaborative and

Table 1

Weekly Schedule for Course Content and Peer Mentoring

\begin{tabular}{|c|c|c|c|c|}
\hline Week & Topic & Before class & Day 1: Lecture-discussion & $\begin{array}{l}\text { Day 2: Workshop with } \\
\text { mentors }\end{array}$ \\
\hline 1 & $\begin{array}{l}\text { Marketing } \\
\text { introduction }\end{array}$ & $\begin{array}{l}\text { Read and complete chapter quizzes on } \\
\text { introducing marketing }\end{array}$ & $\begin{array}{l}\text { Discuss marketing and } \\
\text { developing new products }\end{array}$ & $\begin{array}{l}\text { Form teams of five to six } \\
\text { students following a } \\
\text { personal elevator pitch }\end{array}$ \\
\hline 2 & Marketing strategy & $\begin{array}{l}\text { Read and complete chapter quizzes on } \\
\text { marketing strategy }\end{array}$ & $\begin{array}{l}\text { Discuss marketing strategy and } \\
\text { the marketing environment }\end{array}$ & $\begin{array}{l}\text { Develop SWOT analysis using } \\
\text { secondary resources }\end{array}$ \\
\hline 3 & $\begin{array}{l}\text { Segmentation, } \\
\text { targeting, and } \\
\text { positioning (STP) }\end{array}$ & $\begin{array}{l}\text { Read and complete chapter quizzes on } \\
\text { marketing research, segmentation, } \\
\text { targeting, and positioning }\end{array}$ & $\begin{array}{l}\text { Discuss marketing research, } \\
\text { segmentation, targeting, } \\
\text { and positioning }\end{array}$ & $\begin{array}{l}\text { Develop a primary survey and } \\
\text { STP strategy }\end{array}$ \\
\hline 4 & Pricing strategy & $\begin{array}{l}\text { Read and complete chapter quizzes on pricing } \\
\text { strategy }\end{array}$ & Discuss pricing & $\begin{array}{l}\text { Develop pricing strategy and } \\
\text { financials }\end{array}$ \\
\hline 5 & $\begin{array}{l}\text { Product and place } \\
\text { strategies }\end{array}$ & $\begin{array}{l}\text { Read and complete chapter quizzes on } \\
\text { product and distribution/place strategies }\end{array}$ & $\begin{array}{l}\text { Discuss product, branding, and } \\
\text { packaging and distribution } \\
\text { strategy }\end{array}$ & Develop product strategy \\
\hline 6 & $\begin{array}{l}\text { Midterm course } \\
\text { assessment }\end{array}$ & Study for midterm exam & Midterm exam & $\begin{array}{l}\text { Field trip to campus distribution } \\
\text { center }\end{array}$ \\
\hline 7 & Promotion strategy & $\begin{array}{l}\text { Read and complete chapter quizzes on } \\
\text { promotion strategy }\end{array}$ & $\begin{array}{l}\text { Discuss integrated marketing } \\
\text { communications }\end{array}$ & Develop promotion strategy \\
\hline 8 & Customer analysis & $\begin{array}{l}\text { Read and complete chapter quizzes on } \\
\text { consumer behavior }\end{array}$ & $\begin{array}{l}\text { Discuss consumer and business } \\
\text { marketing }\end{array}$ & $\begin{array}{l}\text { Revise STP on the basis of } \\
\text { primary research results }\end{array}$ \\
\hline 9 & Marketing analytics & $\begin{array}{l}\text { Read and complete chapter quizzes on ethics } \\
\text { and analyze primary data results }\end{array}$ & $\begin{array}{l}\text { Discuss marketing analytics and } \\
\text { marketing ethics }\end{array}$ & Analyze primary data \\
\hline 10 & $\begin{array}{l}\text { Professional selling } \\
\text { and presentation }\end{array}$ & $\begin{array}{l}\text { Read and complete chapter quizzes on } \\
\text { professional selling }\end{array}$ & $\begin{array}{l}\text { Discuss personal selling and } \\
\text { presentations }\end{array}$ & $\begin{array}{l}\text { Present marketing plan } \\
\text { executive summary in a } 5 \\
\text { min pitch format }\end{array}$ \\
\hline
\end{tabular}

Note. ${ }^{2}$ Mentors assisted in Day 2 workshops. 
experiential learning. Instructors observed mentors working with students, reviewed feedback mentors provided students, and shared the feedback.

After each Day 2 workshop, peer mentors met with the faculty coach to share what went well and to discuss improvements. In addition, peer mentors met individually mid-quarter with the faculty coach to discuss individual progress and received timely feedback from each workshop instructor. The creation of an open and receptive atmosphere with free-flowing communicationsalong with food at some weekly meetings and a quarterly dinner-helped motivate and inspire mentors.

\section{METHOD}

\section{Data Collection}

To examine the effect of peer mentoring on content mastery and student perceptions and to assess program design improvements, data were gathered during two consecutive academic quarters. Questions were administered online and outside of class, except for the second quarter's posttest questions, which were embedded in the final exam. Otherwise, response was voluntary although strongly encouraged. No points were given, and reminders were sent. The decision to place the content mastery questions in the second quarter's final exam was to encourage students to complete the questions, especially the essay question, which required more time and effort to complete.

A quasi-experimental design was used, which is classified as an efficacious approach to assessing mentor effectiveness (Gershenfeld, 2014). For each quarter, four sections of the redesigned Principles of Marketing were offered under the direction of three faculty members and eight peer mentors (mentors), and a fifth section (the control) was offered in the traditional format with one faculty member and no peer mentors (no mentors). A total of 604 students were enrolled in the 10 sections; Quarter $1=295$ (mentors $=255$; no mentors $=40$ ) and Quarter $2=309$ (mentors $=245$; no mentors $=64)$. Data were collected from these students on content mastery ( $n=548$; $91 \%$ response rate) and student perceptions of the learning experience ( $n=533 ; 88 \%$ response rate). Data were also collected from the eight peer mentors on leadership practices and their own perceptions of the experience.

\section{Measures}

\section{Content Mastery}

A number of measurements were taken to assess performance and to determine areas for improvement. Content mastery was assessed using 20 multiplechoice questions to measure understanding of these core concepts and an essay question to gauge application on the basis of student usage of 30 predetermined keywords, which were unknown by instructors and mentors delivering the course. A faculty member, who was not teaching the course, selected the multiple-choice questions (level = difficult) from the textbook test bank and wrote the essay question. The multiple-choice questions assessed marketing knowledge. The essay question was focused on application and provided a scenario where students described the marketing-related decisions required to develop and launch a new product. A subset of marketing faculty, which did not include current members of the Principles of Marketing teaching team, had determined the keywords previously, as part of a collegewide assurance of learning effort. Students were required to respond to the 20 multiple-choice questions and the essay both at the beginning (pretest) and at the end (posttest) of the course. Two marketing department assistants read student responses to the essay question for keyword usage as well as appropriate use in context, and tallied counts.

\section{Student Perceptions}

Student perceptions were assessed at the end of the term using an anonymous online survey. Six questions were developed by the authors to examine students' thoughts about different aspects of the learning experience. Students rated their agreement to the following statements, using a 5-point Likert scale:

1. Engagement: "My engagement with this class was high."

2. Learn-by-doing: "This was a true learn-by-doing experience."

3. Learning experience: "I feel this class provided a good learning experience."

4. Learned a lot: "I learned a lot in this class." 
5. In-Class learning: "The in-class experience helped me learn."

- Recommend: "I would recommend this class to another student."

\section{Mentor Leadership Development}

As a measure of leadership development, peer mentors completed the online Student Leadership Practices Inventory (LPI), designed by Kouzes and Posner (2015), at the beginning and at the end of Quarter 1. The LPI tool required mentors to report how frequently they engaged in behaviors related to five leadership practices (Model the Way; Inspire a Shared Vision; Challenge the Process; Enable Others to Act; and Encourage the Heart). Each leadership practice was measured by six items, which respondents evaluated on a five-point frequency scale. The LPI scales have been validated previously and are used extensively in leadership research (Kouzes \& Posner, 2015; Posner \& Kouzes, 1993). Quarter 1 was a training period and changes in mentors' LPI scores from the beginning and the end of Quarter 1 serve as an indicator of leadership development. Mentors were also asked a series of closed- and open-ended questions using an online survey at the end of Quarter 1 . These responses provided a better understanding of their perspectives on the overall experience and informed design improvements and interpretation of the empirical findings.

\section{Program Adjustments Between Quarters 1 and 2}

To identify and implement areas for improvement between Quarter 1 and Quarter 2, questions about the usefulness, effectiveness, and likeability of mentors were included in the anonymous online survey. Students were asked to rate these issues using a five-point scale, and were also given the opportunity to share their thoughts about the course in an open-text field. Responses to the anonymous online survey from Quarter 1 allowed for the identification and implementation of program adjustments in Quarter 2, which are discussed in the program adjustment section of the findings. Moreover, feedback provided in the open-text responses contributed to the interpretation of the findings.

\section{FINDINGS}

\section{Content Mastery}

To examine improvement in content mastery on the basis of the mentor model (Hypothesis 1), a difference score was calculated on the basis of pre- and posttest responses to 20 multiple choice questions and concept usage (keyword) counts in one essay question. The increase in the

\section{Figure 1 \\ Student Improvement in Content Mastery}

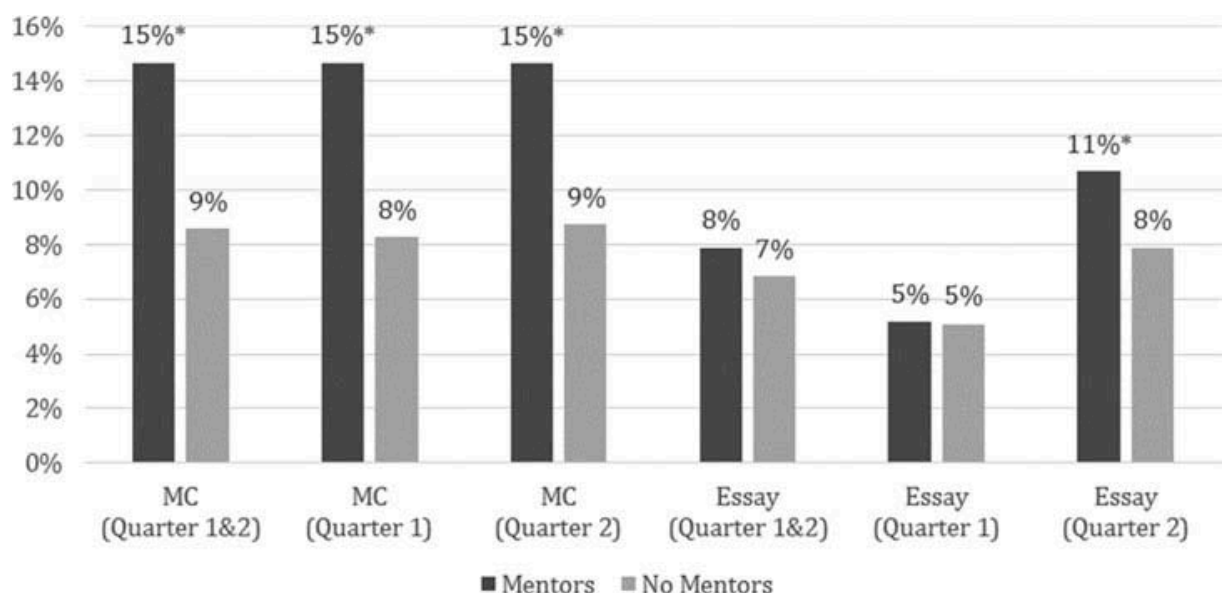

${ }^{*} p<.05$ (one tailed test). 
percentage correct for multiple choice and concept usage counts (essay) are reported for the mentors and no mentors models in Figure 1. An examination of mean differences for both quarters indicate that students perform better under the mentors model for multiple choice $(t$ $[542]=3.33, p<.01)$ but not for essay $(t[511]=1.35$, $p<.10$ ), offering partial support for Hypothesis 1 . For multiple choice, this percentage change difference is significant for both Quarter $1(t[261]=1.91, p<.05)$ and Quarter $2(t[279]=2.85, p<.01)$. For essay, this percentage change difference is not significant for Quarter $1(t$ $[248]=0.11, p>.10)$ but is significant for Quarter $2(t$ $[261]=3.09, p<.01)$.

\section{Student Perceptions}

To understand student perceptions of the learning experience (Hypothesis 2), students were asked to rate various aspects of the course. Figure 2 reports the mean values of student perception for the mentors and no mentors models. In partial support of Hypothesis 2, students rate the mentors model significantly higher than the no mentors model on engagement $(t[531]=4.27, \mathrm{p}<.01)$, learn-by-doing $(t$ $[531]=2.03, p<.05)$, in-class learning $(t[531]=2.83$, $p<.01)$, and would recommend $(t[531]=1.86, p<.05)$, but there is no significant difference for learning experience $(t[531]=1.17, p>.10)$ or learned a lot $(t$ $[531]=1.51, p<.10)$.

\section{Mentor Leadership Development}

Hypothesis 3 examines the effect of mentor leadership development in Quarter 1 on student content mastery in Quarter 2. To gauge the effect of mentor leadership development on student performance, mentor LPI scores from Quarter 1 and student content mastery from Quarter 2 were examined. Quarter 1 LPI scores are a measure of leadership development from the training and direct experiences of the mentors during the first quarter. The values reported in Table 2 are the standardized LPI difference scores for Quarter 1 (Quarter $1_{\text {end_Quarter }} 1_{\text {beginning). Data }}$ are reported for seven mentors, as one mentor was unable to continue in Quarter 2 and was replaced.

On the basis of a median split of Quarter 1 LPI difference scores, there was a significant effect for mentor leadership development on student content mastery for multiple choice $(\mathrm{t}[188]=1.86, p<.05)$ but not for essay $(\mathrm{t}[177]=0.88, p>.10)$, offering partial support of Hypothesis 3. Figure 3 reports the percentage increase in content mastery (multiple choice and essay) on the basis of the degree to which mentors perceived leadership skill as developing.

\section{Figure 2 \\ Student Perceptions of the Learning Experience}

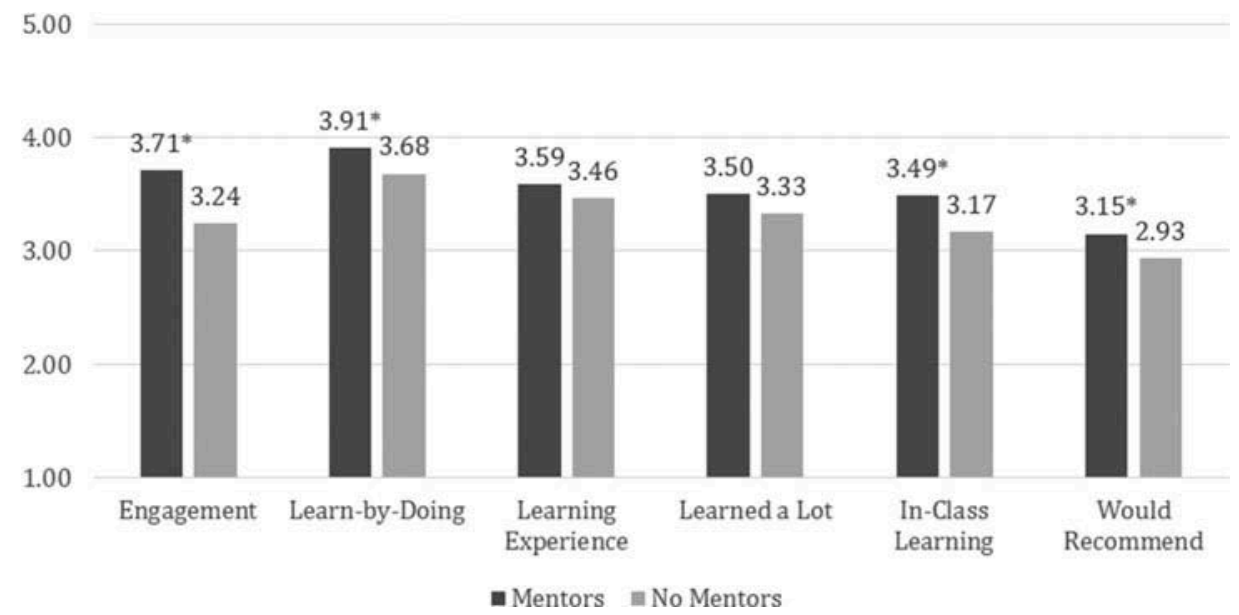

${ }^{*} p<.05$ (one tailed test) 
Table 2

Peer Mentor Standardized LPI Difference Scores for Quarter 1

\begin{tabular}{|c|c|c|c|c|c|c|}
\hline Mentor & $\begin{array}{l}\text { LPI } \\
\text { total }\end{array}$ & Model & Inspire & Challenge & Enable & Encourage \\
\hline A & 1.26 & 1.35 & 0.91 & 1.19 & 1.10 & 1.39 \\
\hline B & 0.97 & 1.35 & 0.91 & 0.04 & 1.10 & 0.46 \\
\hline C & 0.24 & 0.20 & 0.20 & 0.53 & 0.55 & 0.93 \\
\hline D & 0.09 & 0.96 & 0.91 & 0.61 & 0.00 & 0.00 \\
\hline$E$ & 0.02 & 0.49 & 0.08 & 0.90 & 0.55 & 0.46 \\
\hline$F$ & 1.15 & 0.96 & 1.31 & 0.53 & 0.55 & 1.39 \\
\hline G & 1.44 & 0.49 & 1.31 & 1.68 & 1.64 & 0.93 \\
\hline
\end{tabular}

Note. LPI = Leadership Practices Inventory.

To examine the positive effect of specific leadership practices on student learning (Hypothesis 4a-e), difference scores from Quarter 1 were used as a measure of development for each of the five practices, along with pre- and posttest difference scores for multiple choice and essay from Quarter 2. Hierarchical models were estimated for both dependent variables, multiple choice and essay, as this technique considers groupings of student observations. Because some students in the sample were on the same team and had the same mentor, the hierarchical models controlled for the fact that these students were not independent and may have shared similar environmental and social forces with other students. Thus, there were three levels: student, team, and mentor. The Level 1 equation was as follows:

$\mathrm{Y}_{\mathrm{ijk}}=\alpha+\mathrm{b}_{1}\left(\right.$ model $\left._{\mathrm{k}}\right)+\mathrm{b}_{2}\left(\right.$ inspire $\left._{\mathrm{k}}\right)+\mathrm{b}_{3}$ (challen$\left.\mathrm{ge}_{\mathrm{k}}\right)+\mathrm{b}_{4}\left(\right.$ enable $\left._{\mathrm{k}}\right)+\mathrm{b}_{5}\left(\right.$ encourage $\left._{\mathrm{k}}\right)+\varepsilon_{\mathrm{ijk}}$. where $\mathrm{i}=1, \ldots$, I identified the individual student observations, where I $=190$ observations. $\mathrm{j}=1, \ldots, \mathrm{J}$ identified the teams, where $\mathrm{J}=39$ teams. $\mathrm{k}=1, \ldots, \mathrm{K}$ identified the lead mentors, where $\mathrm{K}=7$ lead mentors. $\mathrm{Y}_{\mathrm{ijk}}=$ values of student $\mathrm{i}$ on team $\mathrm{j}$ with lead mentor $\mathrm{k}$ for both variables: understanding and application model $_{\mathrm{k}}=$ the score of mentor k on the "model" criteria of the LPI. inspire $_{\mathrm{k}}=$ the score of mentor $\mathrm{k}$ on the "inspire" criteria of the LPI. challenge $_{\mathrm{k}}=$ the score of mentor $\mathrm{k}$ on the "challenge" criteria of the LPI. enable $_{\mathrm{k}}=$ the score of mentor $\mathrm{k}$ on the "enable" criteria of the LPI. encourage $_{\mathrm{k}}=$ the score of mentor $\mathrm{k}$ on the "encourage" criteria of the LPI.

Level 2 was the identity equation that controlled for student groups. Level 3 was the identity equation that controlled for mentor.

After controlling for lack of independence between students on the same team and with the same mentor, the effect of leadership practices was significant for

Figure 3

Mentor Leadership Development and Student Performance

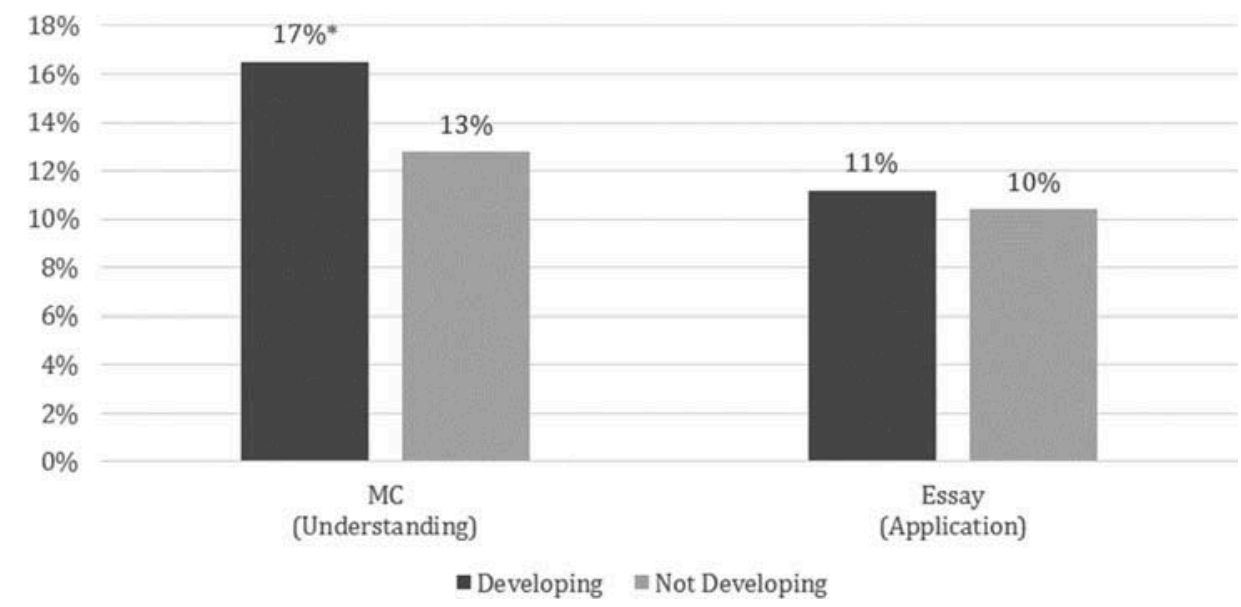

${ }^{*} p<.05$ (one tailed test). 
Table 3

The Effects of Mentor Leadership Practices on Student Performance

\begin{tabular}{lcccr}
\hline $\begin{array}{l}\text { Independent } \\
\text { variables }\end{array}$ & $\begin{array}{c}\text { Beta (multiple } \\
\text { choice) }\end{array}$ & $\boldsymbol{z}$ & $\begin{array}{c}\text { Beta } \\
\text { (essay) }\end{array}$ & $\boldsymbol{z}$ \\
\hline Model & .09 & 1.07 & .11 & 1.30 \\
Inspire & .02 & 0.13 & .13 & .88 \\
Challenge & .12 & 1.15 & .11 & 1.01 \\
Enable & $.31^{*}$ & 2.55 & .06 & .46 \\
Encourage & $.20^{*}$ & 2.07 & .01 & .07 \\
Identity (mentor) & .00 & & .00 & \\
Identity (team) & .00 & & $.79^{*}$ & \\
Snijders/Bosker $R^{2}$ & .16 & & .06 & \\
Wald $\chi^{2}$ (5) & $11.13^{*}$ & & 3.42 & \\
Note. ${ }^{*} p<.05$ (one tailed test). & & & \\
\hline
\end{tabular}

multiple choice (Wald $\chi^{2}(5)=11.13 ; p<.05$ ) but not essay (Wald $\chi^{2}(5)=3.42 ; p>.10$ ). For multiple choice, two of the practices-enable (Hypothesis 4d) and encourage (Hypothesis 4e)-are related to higher student performance, while the other three practicesmodel (Hypothesis 4a), inspire (Hypothesis 4b) and challenge (Hypothesis 4c)-did not make a significant contribution to student performance (see Table 3). For essay, none of the leadership practices contributed to student performance, but the effect of team is significant.

\section{Program Adjustments Between Quarters 1 and 2}

Adjustments to the Mentor Model were made in Quarter 2 on the basis of Quarter 1 feedback. First, Quarter 1 feedback showed that students and instructors experienced a disconnect between the lecture topics on Day 1 and the workshop activities on Day 2. In Quarter 2, instructors addressed this disconnect by aligning more closely Day 1 and Day 2 content. Second, in Quarter 1, students often perceived mentors as teaching assistants and graders. Adjustments made for Quarter 2 included mentor training that stressed the coaching and feedback role of mentors. Third, Quarter 1 students submitted their final marketing plans in sections throughout the quarter without revising each part or compiling the sections into a final document. Students in Quarter 2 revised each section, incorporated mentor feedback, and submitted a final compiled marketing plan. In summary, these changes resulted in stronger linkages between Day 1 and Day 2, stressed the coaching and feedback role of mentors, and allowed students to submit a revised marketing plan at the end of the course.

To examine the effect of program adjustments between Quarter 1 and Quarter 2, a t-test was performed using student ratings of the usefulness, effectiveness and likeability of mentors and Day 2 activities. Students reported that mentors were more effective $(\mathrm{t}(431)=4.31, \mathrm{p}<.01)$, useful $(\mathrm{t}(431)=4.70$, $\mathrm{p}<.01)$, and liked $(\mathrm{t}(431)=3.46, \mathrm{p}<.01)$ in Quarter 2 ; and Day 2 was seen as more effective $(\mathrm{t}(431)=1.86$, $\mathrm{p}<.050)$ and useful $(\mathrm{t}(431)=2.28, \mathrm{p}<.05)$ but no more liked in Quarter $2(\mathrm{t}(431)=1.48, \mathrm{p}<.10)$. These results are summarized in Figure 4.

\section{DISCUSSION}

To contribute to the marketing education literature, this article sets out to examine the effect of peer mentoring on content mastery and to evaluate the efficacy of a peer-mentoring program within a Principles of Marketing course. Overall results demonstrate that peer mentoring has a positive effect on content mastery and student perceptions of the learning experience and that mentor leadership development makes a significant contribution to student learning.

Students who worked with peer mentors demonstrated greater content mastery than those students who did not work with peer mentors. Students that worked with peer mentors rated the course higher on Engagement, Learn-by-Doing, In-class Learning, and Would Recommend than those students who did not have the benefit of working with peer mentors. While students perceived no difference in how good the learning experience was or how much they learned from it, the findings demonstrate an increase in content mastery for those working with peer mentors. Student learning benefited most when working with peer mentors who felt they improved as leaders. This shows the effect of mentor leadership development on student content mastery. When matching the five selfassessed leadership practices of the peer mentors to student performance, two practices-enable and encourage-contributed significantly to student learning; however, the other three practices, model, inspire, and challenge, did not offer a unique contribution to student learning. This finding suggests that when 
Figure 4

\section{Program Design Improvements}

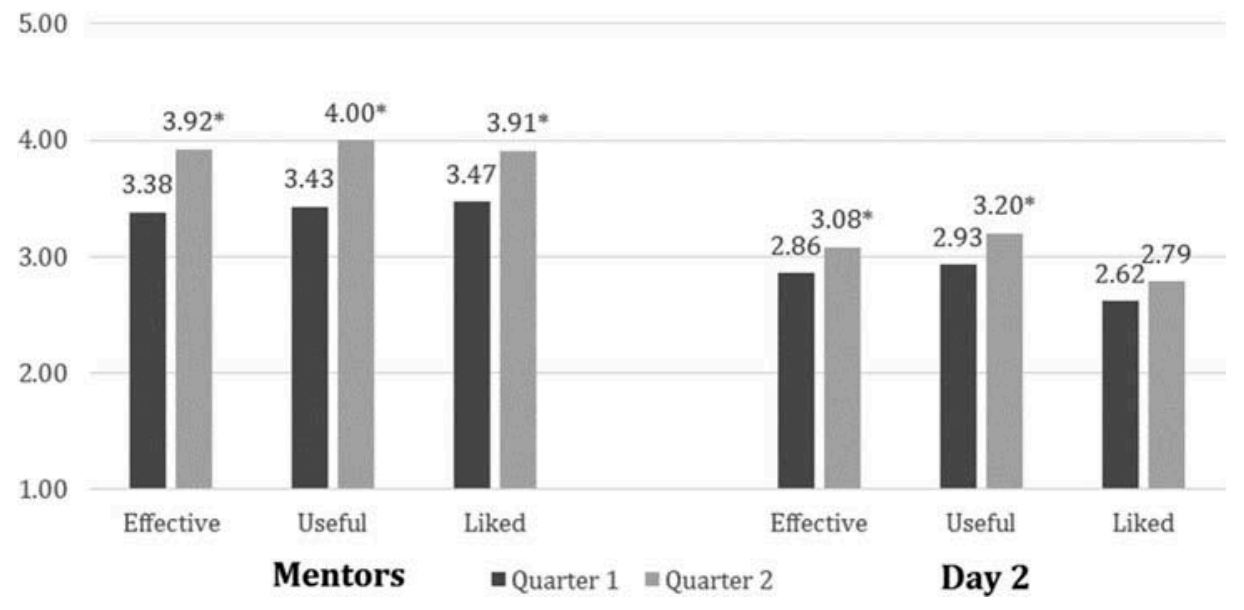

${ }^{*} p<.05$ (one tailed test).

facilitating collaborations among peers in a learning environment, mentors should seek most to involve and to recognize the contributions of others, rather than seek to set an example, to inspire a common purpose, or to challenge the status quo.

This experience was also a learning opportunity for faculty, as feedback was used to improve curriculum and mentor development. First, faculty created greater linkages between the content discussed on Day 1 and the marketing plan project focus on Day 2. On the basis of this improvement, Day 2 was seen as more effective and useful during Quarter 2; however, students did not like Quarter 2's Day 2 any more than they liked Quarter 1's Day 2. An explanation for this may lie in scheduling issues, as Day 2's sessions were held on Fridays when students generally do not have classes. Second, during Quarter 1 peer mentors provided feedback on and suggested grades for each marketing project section. During Quarter 2, faculty stressed a clearer distinction between formative and summative assessments, with peer mentors providing only formative assessment (feedback) and instructors issuing summative assessment (grades). Students responded well to these two changes, as they felt peer mentors were more effective, useful, and liked during Quarter 2 than during Quarter 1. As one student remarked in the online, postcourse survey:
Great class and got me really involved in marketing. I was excited to come class, and the mentors were AWESOME. [Mentor] and [Mentor] were super supportive and helpful and ... provided quality feedback. Get guys like them every year. Great class!

(Student, Quarter 2 online survey comment)

It is also important to note the effect the mentoring experience had on the peer mentors. With a more clearly defined role as coach rather than grader, peer mentors were more successful with students. This is consistent with the findings of others (cf. Bray \& Nettleton, 2007), who found that peer mentors struggled with dual roles as assessor and mentor and experienced role conflict. Similar to what we experienced, Bray and Nettleton (2007) also found that mentors as assessors were poorly received by mentees, who preferred the support of mentors instead. Best practice distinguishes peer mentors from teaching assistants, and indicates that peer mentors should not grade assignments, act as substitute teachers or lecturers, or proctor exams (Smith, 2008). One mentor, when asked what he liked most about working with students during Quarter 2, stated:

I really liked how receptive the students were to me. I also enjoyed the fact that they saw me as 
more of a mentor rather than a professor because last quarter the lines were a bit more blurred.

(Mentor F, Male, Quarter 2 online survey comment)

Peer mentors valued the relationships they developed with students, along with their ability to improve their leadership skills. As one mentor said:

It's cool to think that because I was their mentor, I was able to make some kind of positive impact on their college experience. Ultimately, the best part about being their mentor is making friendships or establishing a sort of mentor/mentee relationship that lasts beyond the quarter we shared in the classroom.

(Mentor D, Female, Quarter 2 online survey comment)

This is consistent with the findings of others. Jacobi (1991) cited the effect the mentoring role has on peer mentors and noted the potential to promote their development and reinforce their engagement with a program. Colvin and Ashman (2010) found that peer mentors valued being able to support students and to develop connections with them.

In addition, peer mentors developed a support system and strong, almost familial, relationships with each other. During weekly meetings, quarterly dinners, and individual conversations, mentors and instructors created bonds strengthening mentors' leadership skills, marketing knowledge, and personal connections. One mentor remarked:

I LOVE MY COWORKERS. I've said it before and I'll say it again. They made this experience into something I never would have ever imagined it to be. I looked forward to every meeting we had on Monday night and every workshop we had on Friday mornings. They made me laugh all the time, but were still incredibly smart influences that were constantly bettering me as a mentor, student and person.

(Mentor C, Male, Quarter 2 online survey comment)

The opportunity to mentor other students brought career benefits to the peer mentors. Importantly, mentors grew as leaders, developing behaviors that encouraged teams to work through problems and to learn collaboratively by involving and recognizing the contributions of peers. Mentors also became expert novices; through the act of mentoring and coaching other students, mentors' marketing content mastery improved. As one mentor shared:

I greatly enjoyed being able to help students in a topic that I am very passionate about. I remember being in their shoes only a few quarters ago, and it feels amazing being able to help them and actively give feedback throughout the entire report. I also am very happy that being a mentor has greatly reinforced my knowledge of the principles of marketing. I feel that I had a great first exposure when I took [Principles of Marketing] for the first time, but going through it again has greatly helped my competency.

(New Mentor, Male, Quarter 2 online survey comment)

As described in Appendix A, implementing a successful peer mentoring program requires several, wellcoordinated steps, including (a) developing a teaching team; (b) planning logistics and obtaining funding; and (c) managing mentors.

\section{CHALLENGES IN IMPLEMENTING A PEER MENTOR PROGRAM}

There were a number of challenges to implementing this course design, which should be acknowledged. The introduction of a new model to a core business course requires coordination and commitment among multiple stakeholders. It demands a high level of involvement among faculty across multiple sections. Peer marketing mentors must be identified, trained, monitored and retained if the benefits to student learning are to be fully realized. This innovation resulted in a course modification, which had to be reviewed by faculty, administrators, and staff at all levels of the college and university. Arranging for lecture and discussion sections on different days required additional scheduling considerations. The ongoing challenge for all stakeholders was overcoming resistance to change and fear of failure, while maintaining a commitment to continuous improvement.

Devoting half of the time in the course to learn-bydoing workshops reduces the number of topics and chapters that can be covered in the Principles of Marketing course especially in a 10-week quarter; however, students may carry more knowledge and a higher level of engagement forward into subsequent marketing courses and into the workplace. During the quarter, content from every textbook chapter was covered 
by requiring students to complete online quizzes outside of class time, so that lectures focused on material most relevant to the mentor-related activities.

Although mentors significantly affected student learning, improved perceptions of learning, and developed leadership skills, there was opportunity for only eight mentors to participate in the program at any given time. Scaling the program so that it provides opportunity for more high-performing marketing students remains a challenge. Mentor continuity is also a challenge, due to graduation, study abroad, co-curricular commitments, and internship opportunities. This challenge can be overcome by leveraging referrals, establishing a recruitment process, developing a knowledge base, and using outgoing mentors to help train and acculturate incoming mentors. It is also important to develop a mentor evaluation process that provides formative feedback, growth opportunities, and consequences for mentors who do not perform well.

\section{LIMITATIONS AND IMPLICATIONS FOR FUTURE RESEARCH}

External validity is limited because the program and study occurred at a single institution with high achieving students; however, the success of a similar program, described by Gosser et al. (2010) for chemistry students provides some assurance of portability and external validity. This suggests research opportunities for faculty at other institutions to implement the peer mentor model and to test its efficacy in institutions with more diverse student populations.

A major limitation of the study was that students were not randomly assigned to a condition, which creates the potential for self-selection and demand bias to influence the outcomes; however, mitigation steps were taken. First, students did not have the opportunity to select sections on the basis of the presence or absence of mentors. The sections were listed identically and no information was provided about the use of mentors (or not) in each section. Second, students were unaware that we were evaluating the effectiveness of the peer-mentor model, so there was no motive to modify behavior.

A third limitation relates to the fact that some of the control and treatment conditions were taught by different instructors. However, many of the results replicated across quarters, with different course times and instructors in the control and treatment conditions, so it is likely the mentor model caused the intended effects, even though we cannot rule out the alternative. Future research could test models in which students and faculty were randomly assigned control and treatment groups.

A fourth limitation involved measurement issues. Although content mastery improved for students under the peer mentor model, the effect was limited to the multiple-choice questions and did not have a clear effect on the essay question. The significant improvement in Quarter 2's essay question may be due to its inclusion in the final exam; whereby, students were more motivated to provide a richer response to this question. In addition, single item measures were used to assess student perceptions, which may not fully capture complex and ambiguous constructs; therefore, some reservation may be warranted in generalizing student reports of the learning experience.

Future research might further examine the effect of mentorship on other learning domains (e.g., application, evaluation, creation) including skills demanded of business professionals: market research to inform customer-led and data-driven marketing; integrated online and offline marketing communications and marketing channels; customer relationship management; and selling and sales management (Harrigan \& Hulbert, 2011; Schlee \& Harich, 2010). Beyond acquisition of knowledge and skills, future research might also examine the role of peer mentors in supporting curiosity and thinking, so they can adapt as marketing practice and the customer and business environments evolve (Hill \& McGinnis, 2007). In addition, the five leadership practices explained only part of the improvement in content mastery. Future research could explore other mentor traits, as noted by Rowley (1999) (e.g., mentor commitment, empathy, experience), and their effect on content mastery, which were not captured by the leadership practices measured in this study.

\section{Conclusion}

This article described a course design that provides a collaborative, hands-on learning experience in an introductory marketing course that was facilitated by peer marketing mentors. Peer mentoring increased content mastery. In addition, students who worked with peer mentors felt they learned more, were more 
engaged, experienced a truer learn-by-doing experience, and would be more likely to recommend the course to others. Developing leadership practices of mentors is an important element to the success of such a mentor program. Peer marketing mentors, along with the faculty team, achieved success in providing a demanding and engaging learning environment that meets the needs of students and equips them with content knowledge required of business professionals.

\section{REFERENCES}

Aderibigbe, S., Antiado, D. F., \& Sta Anna, A. (2015). Issues in peer mentoring for undergraduate students in a private university in the United Arab Emirates. International Journal of Evidence Based Coaching and Mentoring, 13(2), 6480.

Amaral, K. E., \& Vala, M. (2009). What Teaching Teaches: Mentoring and the Performance Gains of Mentors. Journal of Chemical Education, 86(5), 630. doi:10.1021/ ed086p630

Anderson, M. K., Tenenbaum, L. S., Ramadorai, S. B., \& Yourick, D. L. (2015). Near-peer Mentor Model: Synergy within Mentoring. Mentoring \& Tutoring: Partnership in Learning, 117. doi:10.1080/ 13611267.2015.1049017

Arendale, D. R., \& Hane, A. R. (2014). Holistic growth of college peer study group participants: prompting academic and personal development. Research \& Teaching in Developmental Education, 31(1), 7.

Association to Advance Collegiate Schools of Business. (2016). Eligibility Procedures and Accreditation Standards for Business Accreditation.

Batty, J., Rudduck, J., \& Wilson, E. (1999). What makes a good mentor? Who makes a good mentor? The views of year 8 mentees. Educational Action Research, 7(3), 365 374. doi:10.1080/09650799900200099

Bray, L., \& Nettleton, P. (2007). Assessor or mentor? Role confusion in professional education. Nurse Education Today, 27(8), 848 855. doi:10.1016/j.nedt.2006.11.006

Brown, L. M., \& Posner, B. Z. (2001). Exploring the relationship between learning and leadership. Leadership \& Organization Development Journal, 22(6), 274280. doi:10.1108/01437730110403204

Burnett, M. S., \& Pettijohn, C. (1999). Improving Student Performance through Student Mentorships: Practices, Prescriptions and Policies for Enhanced Learning. Marketing Education Review, 9(1), 61 70. doi:10.1080/ 10528008.1999.11488662

Campbell, T. A., \& Campbell, D. E. (1997). Faculty/student mentor program: Effects on academic performance and retention. Research in Higher Education, 38(6), 727742. doi:10.1023/A:1024911904627

Colvin, J. W., \& Ashman, M. (2010). Roles, risks, and benefits of peer mentoring relationships in higher education.
Mentoring \& Tutoring: Partnership in Learning, 18(2), 121 134. doi:10.1080/13611261003678879

Endress, W. L. (2000). An exploratory study of college student self-efficacy for relational leadership: The influence of leadership education, cocurricular involvement, and on-campus employment (Doctoral dissertation), University of Maryland, College Park, MD.

Falchikov, N., \& Blythman, M. (2001). Learning together: Peer tutoring in higher education. New York, NY: Psychology Press.

Finch, D., Nadeau, J., \& O'Reilly, N. (2012). The future of marketing education: A practitioner's perspective. Journal of Marketing Education, 35(1), 5467. doi:10.1177/0273475312465091

Gershenfeld, S. (2014). A review of undergraduate mentoring programs. Review of Educational Research, 84(3), 365 391. doi:10.3102/0034654313520512

Goff, L. (2011). Evaluating the outcomes of a peer-mentoring program for students transitioning to postsecondary education. Canadian Journal for the Scholarship of Teaching and Learning, 2(2), 2. doi:10.5206/cjsotlrcacea

Gosser, Jr, D. K., Kampmeier, J. A., \& Varma-Nelson, P. (2010). Peer-led team learning: 2008 James Flack Norris award address. Journal of Chemical Education, 87 (4), 374 380. doi:10.1021/ed800132w

Gray, M. A., \& Smith, L. N. (2000). The qualities of an effective mentor from the student nurse's perspective: Findings from a longitudinal qualitative study. Journal of Advanced Nursing, 32(6), 1542 1549. doi:10.1046/ j.1365-2648.2000.01606.x

Harrigan, P., \& Hulbert, B. (2011). How can marketing academics serve marketing practice? The new marketing DNA as a model for marketing education. Journal of Marketing Education, 33(3), 253 272. doi:10.1177/ 0273475311420234

Hershatter, A., \& Epstein, M. (2010). Millennials and the world of work: An organization and management perspective. Journal of Business and Psychology, 25(2), 211 223. doi:10.1007/s10869-010-9160-y

Hill, M. E., \& McGinnis, J. (2007). The curiosity in marketing thinking. Journal of Marketing Education, 29(1), 5262. doi:10.1177/0273475306297385

Jacobi, M. (1991). Mentoring and undergraduate academic success: A literature review. Review of Educational Research, 61(4), $505532 . \quad$ doi:10.3102/ 00346543061004505

Kleine, S. S. (2002). Enhancing students' role identity as marketing majors. Journal of Marketing Education, 24(1), 15 23. doi:10.1177/0273475302241003

Kouzes, J., \& Posner, B. (2015). The leadership challenge. Retrieved from http://www.leadershipchallenge.com

Kram, K. E. (1988). Mentoring at work: Developmental relationships in organizational life. New York, NY: University Press of America.

Kuh, G. D. (2008). High-Impact Educational Practices: What They Are, Who Has Access to Them, and Why They Matter. Washington, DC: Association of American Colleges and Universities. 
Lankau, M. J., \& Scandura, T. A. (2002). An investigation of personal learning in mentoring relationships: Content, antecedents, and consequences. Academy of Management Journal, 45(4), 779 790. doi:10.2307/3069311

Longfellow, E., May, S., Burke, L., \& Marks-Maran, D. (2008). 'They had a way of helping that actually helped': A case study of a peer-assisted learning scheme. Teaching in Higher Education, 13(1), 93 105. doi:10.1080/ 13562510701794118

Parker, P., Hall, D. T., \& Kram, K. E. (2008). Peer coaching: A relational process for accelerating career learning. Academy of Management Learning \& Education, 7(4), 487 503. doi:10.5465/AMLE.2008.35882189

Posner, B. Z. (2004). A leadership development instrument for students: Updated. Journal of College Student Development, 45(4), 443 456. doi:10.1353/csd.2004.0051

Posner, B. Z., \& Kouzes, J. M. (1993). Psychometric properties of the leadership practices inventory-updated. Educational and Psychological Measurement, 53(1), 191 199. doi:10.1177/0013164493053001021

Raska, D., Keller, E. W., \& Shaw, D. (2013). Using web-based peer benchmarking to manage the client-based project. Marketing Education Review, 23(1), 23 30. doi:10.2753/ MER1052-8008230104

Rieske, L. J., \& Benjamin, M. (2015). Utilizing peer mentor roles in learning communities. New Directions for Student Services, 2015(149), 67 77. doi:10.1002/ss.2015.2015. issue-149

Roscoe, R. D., \& Chi, M. T. H. (2007). Understanding tutor learning: Knowledge-building and knowledge-telling in peer tutors' explanations and questions. Review of Educational Research, 77, 534 574. doi:10.3102/ 0034654307309920

Rowley, J. B. (1999). The good mentor. Educational Leadership, 56(8), 2022.
Schlee, R. P., \& Harich, K. R. (2010). Knowledge and skill requirements for marketing jobs in the 21st century. Journal of Marketing Education, 32(3), 341352. doi:10.1177/0273475310380881

Schon, D. A. (1983). The reflective practitioner: How professionals think in action. New York, NY: Basic Books.

Sherman, J. D., \& Burns, H. L. (2015). 'Radically different learning': Implementing sustainability pedagogy in a university peer mentor program. Teaching in Higher Education, 20 (3), 231 243. doi:10.1080/13562517.2014.993962

Smith, K. K. (2012). Preparing students for after-college life: The context. New Directions For Student Services, 2012 (138), 5 12. doi:10.1002/ss.v2012.138

Smith, T. (2008). Integrating undergraduate peer mentors into liberal arts courses: A pilot study. Innovative Higher Education, 33(1), 49 63. doi:10.1007/s10755007-9064-6

Stevenson, L., Fox, F., Connelly, P., Duff, A., \& Dunlop, A. (2010). E Peer-mentoring undergraduate accounting students: The influence on approaches to learning and academic performance. Active Learning in Higher Education, 11(2), $145156 . \quad$ doi:10.1177/ 1469787410365650

Taylor, E. W. (2007). An update of transformative learning theory: A critical review of the empirical research (1999 2005). International Journal of Lifelong Education, 26(2), 173 191. doi:10.1080/02601370701219475

Tenenbaum, L. S., Anderson, M. K., Jett, M., \& Yourick, D. L. (2014). An Innovative Near-Peer Mentoring Model for Undergraduate and Secondary Students: STEM Focus. Innovative Higher Education, 39(5), 375385. doi:10.1007/s10755-014-9286-3

Topping, K. J. (2005). Trends in Peer Learning. Educational Psychology, 25(6), $631645 . \quad$ doi:10.1080/ 01443410500345172 


\section{Appendix \\ Suggestions for Implementation: A Step-by-Step Guide ${ }^{1}$}

\section{DEVELOP TEACHING TEAM}

Plan course

Develop materials

Create rubrics

Select coach
Meet to determine what will occur during Day 1 "lecture" and Day 2 "workshop"; coordinate goals, distribute workload, and set consistent expectations

Develop course materials, including syllabus and marketing plan guidelines

Create rubrics for each marketing plan section; include exemplars of strong and poor work

Select a faculty coach who, working with the teaching team, will select, train, and supervise mentors

\section{PLAN LOGISTICS AND FUNDING}

Schedule facilities

Obtain funding
Day 1: A room appropriate for lecture and discussion

Day 2: Collaborative workspace helps facilitate teamwork

Determine the budget requirements, obtain funding, and follow employee payroll process; for example, mentors earned $\$ 12$ per hour for ten hours each week and were paid as student employees

\section{MANAGE MENTORS}

Set criteria

Recruit mentors

Interview and select mentors
Consider major/concentration, GPA, experience

Solicit faculty nominations of high performing marketing students and invite interested students to nominate themselves

Create an application

Request nominated students submit the application and resume to faculty coach

Develop a list of interview questions

Review student applications

Interview candidates and select student mentors

Notify all candidates in a timely manner: selected; deferred to another quarter (perhaps too early in their academic career); or rejected

Train mentors

Set a weekly meeting time and location, preferably early in the week

Develop a training schedule focusing on leadership skills, coaching techniques, marketing knowledge, workshop strategy, and problem solving tools; schedule guest speakers for additional expertise

Create an agenda for that week's meeting; float the agenda to teaching team for feedback

Schedule debrief meetings with mentors following each weekly workshop to discuss what went well and what needs improvement; weekly sessions allow issues to be discussed while still top of mind

Motivate mentors

Meet individually with each mentor at least once, preferably twice, each quarter to discuss individual progress

Encourage rapport and support between workshop instructors and mentors, allowing for timely praise and feedback during workshop sessions

Motivate and inspire mentors while creating a collaborative team with snacks at weekly meetings and quarterly dinners

Monitor mentors
During workshops, observe mentors as they work with student teams, noting strengths and areas of improvement

As soon as possible, provide ongoing feedback to mentors

Meet quarterly with individual mentors to allow for additional feedback

\section{DESIGN MARKETING PLAN PROJECT}

Assign mentors to teams
Pair mentors so each mentor works with three teams as lead mentor and provides feedback on his/ her mentor partner's three teams' marketing plan assignments thus each team receives feedback from two mentors 
Appendix

(Continued)

DESIGN MARKETING PLAN PROJECT

Review rubrics and exemplars

Direct mentors to meet with teams

Coach mentors on providing feedback
Review, at the start of each workshop, that day's rubric and exemplars with the class, setting expectations for that day's assignment

Direct mentors, during workshops, to meet individually with their three teams to discuss past progress and the current assignment

Instruct each team to write one to two sections of the marketing plan each week (see sample syllabus) using Google docs (folder shared with each team member, lead and co mentors, and instructor)

Coach mentors on providing feedback on each submitted marketing plan section, using Google docs "suggestions" and "commenting" tools

Encourage students to review mentor and instructor feedback, incorporating these suggestions into their final marketing plan

Stress difference between formative and summative assessment
Grade each marketing plan section and the final marketing plan; stress mentors share feedback and instructors assign grades

Note. ${ }^{1}$ The marketing plan project guidelines, marketing plan project rubrics and exemplars, mentor application, and mentor training schedule are available from the authors upon request. 